\title{
Qualidade fisiológica de sementes de soja colhidas em duas épocas após dessecação com glyphosate ${ }^{1}$
}

\author{
Mariana Zampar Toledo²*, Cláudio Cavariani², José de Barros França-Neto ${ }^{3}$
}

RESUMO - A dessecação de plantas de soja em pré-colheita com glyphosate vem se tornando prática rotineira entre os produtores, apesar de não ser recomendada, pois pode comprometer a qualidade fisiológica das sementes. Objetivou-se avaliar os efeitos da dessecação das plantas em pré-colheita com glyphosate na qualidade fisiológica de sementes de soja colhidas em duas épocas após a aplicação. O delineamento experimental foi em blocos ao acaso, com quatro repetições, em esquema de parcelas subdivididas. As parcelas principais consistiram da dessecação ou não das plantas de soja com glyphosate em pré-colheita, no estádio R7, e as subparcelas da colheita das sementes 7 e 14 dias após a aplicação. As sementes foram avaliadas quanto ao teor de água, dano mecânico, viabilidade, massa de 100 sementes e teor de proteína. A qualidade fisiológica foi avaliada por meio dos testes de germinação, envelhecimento acelerado, condutividade elétrica, comprimento de plântulas e massa da matéria seca das plântulas. A dessecação das plantas de soja em pré-colheita com glyphosate ocasiona redução da germinação das sementes e do desenvolvimento inicial das plântulas. $\mathrm{O}$ atraso na colheita reduz a germinação das sementes oriundas de plantas de soja dessecadas com glyphosate em pré-colheita, mas minimiza os efeitos fitotóxicos no desenvolvimento das plântulas.

Termos para indexação: Glycine max, fitotoxicidade, germinação, maturidade fisiológica.

\section{Physiological quality of soybean seeds harvested at two periods after glyphosate desiccation}

\begin{abstract}
Pre-harvest desiccation of soybean plants with glyphosate has been routinely conducted by seed producers, although it is not recommended because it may reduce seed physiological quality. The objective of this study was to evaluate the effects of the pre-harvest desiccation of plants with glyphosate on the physiological quality of soybean seeds harvested at two different periods after application. The experimental design was completely randomized blocks, with four replications and subdivided plots. Main plots consisted of the presence and absence of a pre-harvest desiccation of soybean plants with glyphosate at the R7 stage, and subplots of seeds harvested 7 and 14 days after application. Moisture content, mechanical damage, viability, weight of 100 seeds, protein content and accumulation of glyphosate residues were determined after harvest. Physiological quality was evaluated by tests for germination, accelerated aging, electrical conductivity, seedling length and seedling dry matter. Pre-harvest desiccation of soybean plants with glyphosate reduces seed germination and seedling development. Delayed harvesting reduces the germination of soybean seeds produced by plants desiccated with glyphosate, but minimizes phytotoxicity in seedling development.
\end{abstract}

Index terms: Glycine max, phytotoxicity, germination, physiological maturity.

${ }^{1}$ Submetido em 02/03/2011. Aceito para publicação em 06/07/2011.

${ }^{2}$ Universidade Estadal de Maringá, 8751-970 - Umuarama, PR, Brasil.
${ }^{3}$ Embrapa Soja, Caixa Postal 231, 86001-970 - Londrina, PR, Brasil.

*Autor para correspondência < zampar_@hotmail.com> 


\section{Introdução}

Durante o processo de formação e maturação das sementes, são verificadas alterações de massa de matéria seca, grau de umidade, tamanho, germinação e vigor, sendo maior qualidade fisiológica observada no estádio denominado maturidade fisiológica (Carvalho e Nakagawa, 2000) ou R7 (Fehr e Caviness, 1977).

A colheita de sementes de soja neste estádio seria, teoricamente, o mais indicado, pois é o momento em que o grau de deterioração é mínimo (Carvalho e Nakagawa, 2000). No entanto, em soja, o teor de água durante a maturidade fisiológica varia entre 45 e 60\% (Marcos-Filho, 2005), impossibilitando a colheita mecânica. Assim, a utilização de herbicidas dessecantes é alternativa passível de emprego por produtores, visando antecipar e facilitar a colheita e minimizar a rápida deterioração da qualidade das sementes no campo (Inoue et al., 2003).

A aplicação de herbicidas dessecantes acelera o processo de perda de água pelas plantas e, consequentemente, das sementes, diminuindo o período de exposição prolongada a fatores bióticos e abióticos após a maturidade fisiológica (Hamer e Hamer, 2003). Deste modo, alguns trabalhos revelaram resultados positivos em relação à eficácia de dessecantes quanto à redução do teor de água e preservação da qualidade de sementes de soja (Lacerda et al., 2003; Kappes et al., 2009).

No entanto, a dessecação da soja em pré-colheita não deve ser encarada como uma prática rotineira. Apesar de inúmeros estudos terem constatado produção de sementes de soja com melhor qualidade por efeito da dessecação em pré-colheita, a aplicação é, ainda, somente recomendada para produção de grãos (Tecnologias, 2008). A razão para tanto é a possibilidade de alguns dessecantes deixarem resíduos, causadores de redução no vigor das sementes, ou então, promoverem rápido desenvolvimento de fungos nas hastes, vagens e sementes.

Apesar de não recomendada, a dessecação em précolheita de campos de produção de sementes de soja com glyphosate tem sido realizada em diversas regiões do Brasil (Tecnologias, 2008) devido, principalmente, em função da baixa relação custo-benefício do produto em relação a outros herbicidas (França-Neto et al., 2007). O glyphosate [N-(phosphonomethyl) glycine] é um herbicida pós-emergente e de ação sistêmica, pertencente ao grupo químico das glicinas substituídas (Vargas et al., 2007).

Apesar de frequente, o uso do glyphosate como dessecante pode acarretar reduções na germinação e vigor das sementes. Gazziero e França-Neto (2008), em avaliações da qualidade de sementes de três tamanhos das cultivares Conquista e Xingu, aplicaram glyphosate em pré-colheita e verificaram efeito negativo da dessecação no comprimento das plântulas de ambos os materiais.

Daltro et al. (2010) evidenciaram, por duas safras agrícolas, a ação negativa do herbicida glyphosate sobre o potencial fisiológico das sementes de soja de cultivares não portadoras do gene de resistência a esse produto. Os autores verificaram prejuízos ao desempenho das sementes, causados por efeito fitotóxico, traduzido por sintomas característicos nas raízes das plântulas.

No estádio de maturidade fisiológica, ou R7 (Fehr e Caviness, 1977), a translocação de fotoassimilados da planta para a semente é cessada (Carvalho e Nakagawa, 2000). Deste modo, os efeitos do glyphosate, ou de quaisquer dessecantes, aplicados após o citado estádio não deveriam comprometer a qualidade fisiológica das sementes colhidas posteriormente, independentemente do período decorrido entre a colheita e a aplicação.

Com esta pesquisa temos como objetivo avaliar os efeitos da dessecação das plantas em pré-colheita com glyphosate na qualidade fisiológica de sementes de soja colhidas em duas épocas após a aplicação.

\section{Material e Métodos}

O experimento foi instalado e conduzido em área da Fazenda Experimental Lageado, na Faculdade de Ciências Agronômicas, FCA/UNESP, Botucatu-SP. O solo da área é classificado como Latossolo Vermelho distroférrico de textura argilosa (Embrapa, 2006). A localização da área experimental está definida pelas coordenadas geográficas $22^{\circ} 49^{\prime} \mathrm{S}$ e $48^{\circ} 25^{\prime} \mathrm{W}$, com altitude média de 770 metros e declividade de 0 a $3 \%$. Segundo a classificação de Köeppen, o clima predominante na região é do tipo Cwa, com precipitação média anual em torno de $1.600 \mathrm{~mm}$.

Os dados climáticos foram coletados mensalmente na estação meteorológica da Fazenda Experimental Lageado, próxima à área experimental (Figura 1).

O delineamento experimental utilizado no campo foi o de blocos ao acaso, com quatro repetições, em esquema de parcelas subdivididas. As parcelas principais corresponderam à ausência e presença de dessecação com glyphosate em pré-colheita e as subparcelas às épocas de colheita, quais sejam 7 e 14 dias após a aplicação do glyphosate. 


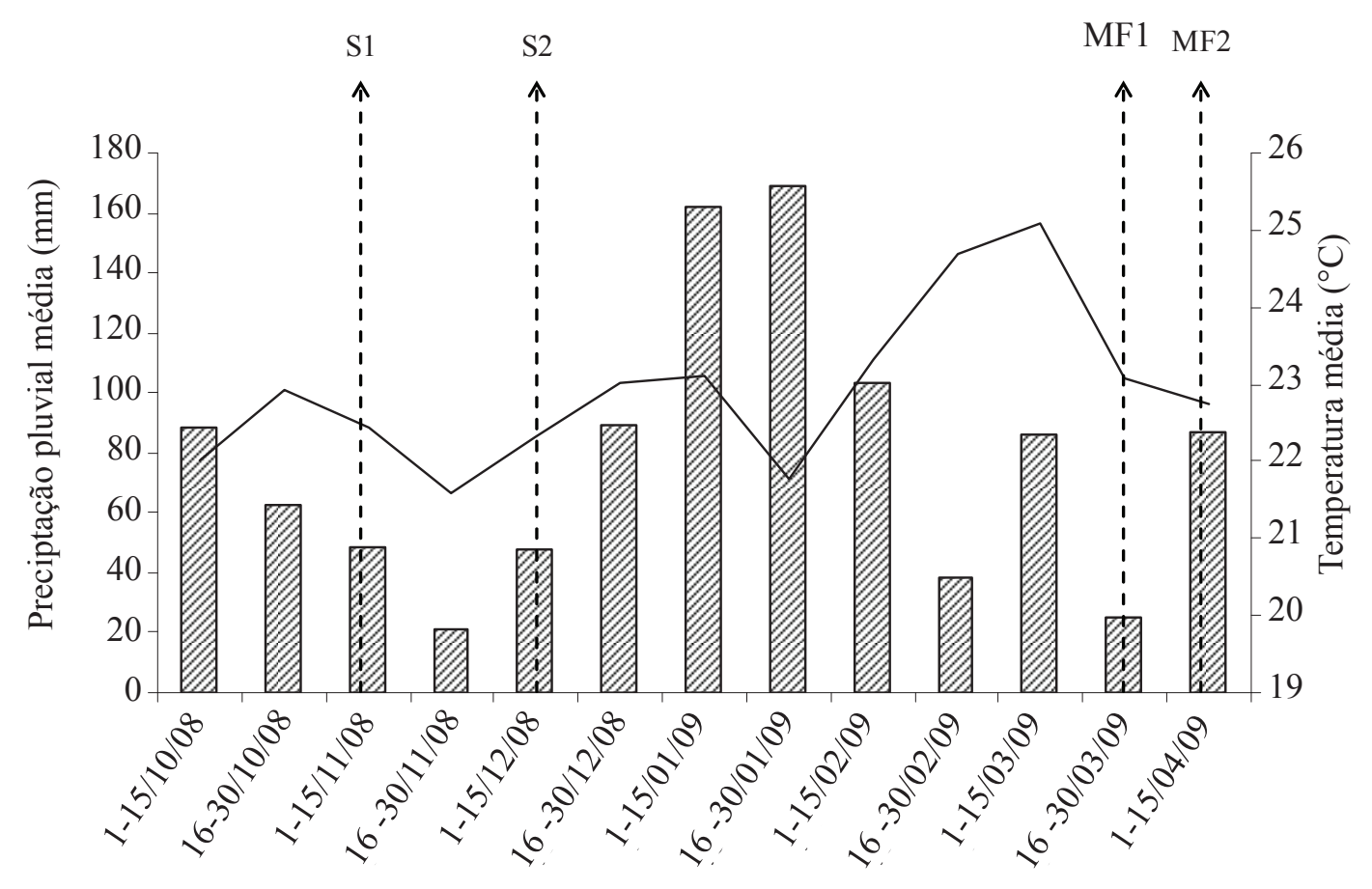

Figura 1. Precipitação pluvial ( $\dddot{Z}$ ) e temperatura (-) durante o período de produção das sementes. S: semeadura; MF: maturidade fisiológica.

A área foi dividida em quatro blocos de $24 \mathrm{~m}$ de comprimento por $12 \mathrm{~m}$ de largura. A área de cada uma das duas parcelas principais foi de $12 \mathrm{~m}$ de comprimento por 5 $\mathrm{m}$ de largura. As subparcelas tinham $6 \mathrm{~m}$ de comprimento por $5 \mathrm{~m}$ de largura. As subparcelas foram separadas por uma distância de $2 \mathrm{~m}$ no sentido da largura e por $4 \mathrm{~m}$ no sentido do comprimento. Um carreador de $4 \mathrm{~m}$, entre os blocos, foi utilizado para facilitar o acesso com veículos. As dimensões das parcelas e dos carreadores foram estipuladas para possibilitar as operações de pulverização.

A semeadura da cultivar convencional Conquista foi realizada mecanicamente, em área coberta por palhada de milheto, em 04/11/2008, utilizando-se sementes previamente tratadas com o fungicida carboxin+thiram (Vitavax Thiram $\mathrm{SC}^{\circledR}$ ) e inoculante $\left(\right.$ Biomax $\left.^{\circledR}\right)$, e espaçamento de $0,45 \mathrm{~m}$ entre linhas, visando a obtenção de população equivalente a 400.000 plantas ha ${ }^{-1}$. A adubação de semeadura foi realizada de acordo com resultados da análise química do solo (Raij et al., 1996) e constou da aplicação de $300 \mathrm{~kg} \mathrm{ha}^{-1}$ da formulação NPK 04-20$20 \mathrm{em}$ área total. Não houve necessidade de aplicações posteriores de nutrientes em cobertura.

A aplicação do herbicida glyphosate, na dose de 2,0 $\mathrm{L} \mathrm{ha}^{-1}$ do produto comercial Roundup $\mathrm{WG}^{\circledR}\left(720 \mathrm{~g} \mathrm{~kg}^{-1} \mathrm{de}\right.$ equivalente ácido) foi realizada na maturidade fisiológica das sementes, ou R7. O estádio R7 foi identificado através da coloração das vagens, em sua maioria amarelas, com uma delas totalmente madura na haste principal, conforme estabelecido por (Fehr e Caviness 1977). A aplicação foi realizada com pulverizador de barras, munidas com pontas tipo leque, modelo TJ 11004 , espaçados em $0,5 \mathrm{~m}$,

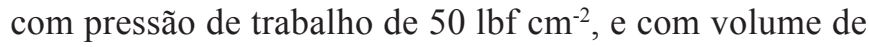
calda de $200 \mathrm{~L} \mathrm{ha}^{-1}$.

Nas unidades experimentais referentes à colheita realizada sete dias após a dessecação, as plantas foram manualmente cortadas, rente ao solo, e colocadas para secagem à sombra; as sementes foram obtidas após debulha das plantas inteiras em trilhadeira estacionária, em razão de se encontrarem secas. Nas demais parcelas, 14 dias depois, as sementes foram colhidas com uma colhedora de parcelas automotriz. Os métodos de colheita foram estabelecidos considerando-se o teor de água das sementes, a fim de minimizar a ocorrência de danos mecânicos. A colheita foi realizada em 6 linhas de $6 \mathrm{~m}$ de comprimento, totalizado uma área de $16,2 \mathrm{~m}^{2}$.

As avaliações da qualidade fisiológica das sementes de soja após as colheitas foram conduzidas no Laboratório de Análise de Sementes, do Departamento de Produção Vegetal/Agricultura, Faculdade de Ciências Agronômicas, UNESP, campus de Botucatu-SP. 
As sementes foram armazenadas em embalagens de papel e mantidas em ambiente natural, sem controle da temperatura e umidade relativa do ar, durante o período das avaliações, que constaram dos seguintes testes/ determinações:

Teor de água: foram empregadas duas repetições de 20 sementes e o método da estufa elétrica de desidratação, sem ventilação forçada, a $105 \pm 3{ }^{\circ} \mathrm{C}$ durante 24 horas (Brasil, 1992).

Teste de tetrazólio: com o objetivo de verificar a porcentagem de sementes viáveis (classes 1-5), 200 sementes para cada tratamento foram pré-condicionadas em papel toalha umedecido com quantidade de água equivalente a 2,5 vezes a sua massa seca, durante 16 horas, em germinador regulado à temperatura de $25^{\circ} \mathrm{C}$. Após este período, as sementes foram colocadas em um becker, imersas em uma solução de concentração de $0,075 \%$ de 2,3,5-trifenil-cloreto-de-tetrazólio e, em seguida, mantidas no escuro, em estufa com temperatura de $35{ }^{\circ} \mathrm{C}$, por três horas, para o desenvolvimento da coloração. Após lavagem em água corrente, as sementes foram avaliadas individualmente, conforme metodologia descrita por (França-Neto et al. 1998).

Dano mecânico (hipoclorito de sódio): realizada de acordo com Krzyzanowski et al. (2004), quatro repetições de 50 sementes por tratamento foram imersas durante 10 minutos numa solução diluída de hipoclorito de sódio, com concentração de $0,2 \%$. Posteriormente, o excesso da solução foi eliminado e as sementes distribuídas sobre folhas de papel toalha para determinação da porcentagem de sementes intumescidas (danificadas). Os resultados foram expressos em porcentagem.

Teste de condutividade elétrica: consistiu da disposição de quatro repetições de 50 sementes por tratamento, com massas conhecidas, em recipientes plásticos com $75 \mathrm{~mL}$ de água destilada. Os recipientes foram mantidos em germinador regulado a $25{ }^{\circ} \mathrm{C}$ por 24 horas para, a seguir, proceder-se leitura com condutivímetro (Vieira e Krzyzanowski, 1999). O resultado foi expresso em $\mu \mathrm{S} \mathrm{cm}^{-1} \mathrm{~g}^{-1}$, dividindo-se a leitura pela massa das sementes.

Teor de proteína: quatro repetições de $0,1 \mathrm{~g}$ por amostra foram utilizadas para cada tratamento. $\mathrm{O}$ teor de proteína foi determinado a partir do conteúdo de nitrogênio total da semente, determinado pelo método micro-Kjeldhal, utilizando o fator 6,25 para converter o nitrogênio em proteína (AOAC, 1990).
Massa de 100 sementes: realizada conforme adaptação de instruções de Brasil (1992), oito repetições de 100 sementes por tratamento foram contadas e tiveram suas massas determinadas; os resultados foram expressos em gramas.

Teste de germinação: quatro repetições de 50 sementes por tratamento foram dispostas em rolos de papel toalha, umedecidos com água destilada em quantidade correspondente a 2,5 vezes a massa do papel seco. Os rolos confeccionados permaneceram acondicionados em sacos plásticos fechados e mantidos em um germinador regulado à temperatura de $25{ }^{\circ} \mathrm{C}$ por oito dias. Em avaliação no oitavo dia (Brasil, 1992), foram computadas as porcentagens de plântulas normais e anormais.

Teste de envelhecimento acelerado: as sementes de cada tratamento foram dispostas sobre tela no interior de caixas plásticas, em camada única, sem entrarem em contato com os $40 \mathrm{~mL}$ de água destilada contidos no fundo (Marcos-Filho, 1999). As caixas foram fechadas e mantidas no interior de sacos plásticos a $42{ }^{\circ} \mathrm{C}$ por 72 horas. Imediatamente após o término do período de envelhecimento, quatro repetições de 50 sementes, em rolos de papel toalha, foram expostas às mesmas condições descritas para o teste de germinação, porém avaliando-se a porcentagem de plântulas normais aos cinco dias após a semeadura.

Comprimento de plântulas: foi determinado com o emprego de quatro repetições de 10 sementes por tratamento dispostas sobre linha traçada no terço superior do papel, no sentido longitudinal. Os substratos, na forma de rolos, foram colocados em sacos plásticos, para evitar a desidratação, e mantidos, verticalmente, em germinador regulado a 25 ${ }^{\circ} \mathrm{C}$ por cinco dias, na ausência de luz (Nakagawa, 1999). Decorrido este período, o comprimento da raiz primária e do hipocótilo foram medidos separadamente e o comprimento calculado pelo quociente entre a soma das medidas e o número de sementes utilizadas no teste, para cada repetição (Vanzolini et al., 2007).

Massa de matéria seca de plântulas: foi determinada utilizando-se as plântulas obtidas ao final do teste de comprimento que, colocadas separadamente em sacos de papel, foram secas em estufa com circulação forçada de ar à temperatura de $80{ }^{\circ} \mathrm{C}$, durante 24 horas. Os cálculos foram efetuados dividindo-se a massa obtida pelo número de plântulas contidas em cada rolo de papel (Nakagawa, 1999); com expressão dos resultados em mg por plântula. 
Com exceção do teor de água, os dados foram submetidos à análise de variância e as médias comparadas pelo teste de Tukey a $5 \%$ de probabilidade, em esquema fatorial 2 × 2 (presença e ausência de dessecação x época de colheita).

\section{Resultados e Discussão}

De acordo com a Tabela 1, o teor de água das sementes, sete dias após a dessecação das plantas com glyphosate, foi reduzido em relação ao grau de umidade verificado no momento da aplicação. Os valores referentes às sementes produzidas na ausência de dessecação também foram inferiores, já que, após a maturidade fisiológica, verifica- se um processo de secagem natural, que prossegue até que as sementes atinjam um ponto de equilíbrio com a umidade relativa do ar (Marcos-Filho, 2005); entretanto, observa-se que a redução foi menos drástica na primeira semana após a aplicação. Outros autores também constataram redução do teor de água das sementes de soja e, consequentemente, antecipação da colheita após dessecação das plantas, porém com os herbicidas paraquat e diquat (Lacerda et al., 2003; Kappes et al., 2009). Daltro et al. (2010) anteciparam a colheita das sementes de soja em torno de dois dias após aplicação de paraquat, diquat, [paraquat+diquat] e [paraquat+diuron], mas verificaram efeito mais lento após dessecação com glyphosate comparativamente aos demais produtos.

Tabela 1. Teor de água (\%) de sementes de soja colhidas em diferentes épocas após a dessecação com glyphosate.

\begin{tabular}{|c|c|c|c|}
\hline \multirow{2}{*}{ Época } & \multirow{2}{*}{ Dias após Aplicação } & \multicolumn{2}{|c|}{ Condição de dessecação } \\
\hline & & Com & Sem \\
\hline \multirow{3}{*}{ Na colheita } & $0^{(1)}$ & 58,43 & 58,21 \\
\hline & 7 & 27,57 & 34,44 \\
\hline & 14 & 13,37 & 13,93 \\
\hline \multirow{2}{*}{ Anteriormente às análises } & 7 & 10,8 & 12,1 \\
\hline & 14 & 7,8 & 7,8 \\
\hline
\end{tabular}

${ }^{(1)}$ maturidade fisiológica das sementes

Sementes de soja colhidas com teores de água entre $13 \%$ e $15 \%$ têm minimizados os problemas de danos mecânicos e perdas na colheita (Tecnologias, 2008). Deste modo, mesmo após uso do glyphosate como dessecante, ainda não seria possível realizar a colheita mecânica, considerando-se que o teor de água ainda apresentavase maior que os do intervalo citado (Tabela 1). Somente 14 dias após a aplicação, teores de água compatíveis com o manejo mecanizado foram observados, havendo, ainda, similaridade entre os valores obtidos na presença e ausência de dessecação.

Os teores de água das sementes diminuíram após a colheita proporcionalmente aos conteúdos verificados em campo (Tabela 1); portanto, anteriormente às análises de qualidade, os graus de umidade não foram uniformes, já que o equilíbrio higroscópico varia em função da temperatura, do teor de água inicial e de condições intrínsecas da semente (Carvalho e Nakagawa, 2000), mas mantiveram-se baixos e não influenciaram os resultados de qualidade.
A massa de sementes, a porcentagem de plântulas normais e anormais do teste de germinação, e o desenvolvimento das plântulas de soja foram influenciados significativamente pela combinação entre dessecação em pré-colheita com glyphosate e época de colheita das sementes após a aplicação do herbicida (Tabela 2). Os resultados das demais avaliações variaram em função dos tratamentos isoladamente, excetuandose os dados de viabilidade das sementes, que não foram afetados por nenhum deles.

A viabilidade das sementes de soja não foi influenciada pela dessecação química com glyphosate (Tabela 3), à semelhança do constatado por Daltro et al. (2010), que, ao avaliar o vigor e da viabilidade das sementes de soja por meio do teste de tetrazólio, não verificaram efeitos de épocas de dessecação, épocas de colheita e produtos dessecantes ou diferenças entre os tratamentos e a testemunha. Assim como observado no presente trabalho, os autores atribuíram a ausência de significância ao vigor inicial muito alto das sementes, superior a $85 \%$. 
Tabela 2. Análise de variância dos dados de qualidade das sementes de soja colhidas em diferentes épocas após a dessecação com glyphosate.

\begin{tabular}{ccccc}
\hline \multirow{2}{*}{ Avaliação } & C.V. $(\%)$ & \multicolumn{3}{c}{ Fcalc } \\
\cline { 3 - 4 } & & Dessecação & Dias após a aplicação & Interação \\
\hline TZ $1-5$ & 3,14 & $0,066 \mathrm{~ns}$ & $0,066 \mathrm{~ns}$ & $2,643 \mathrm{~ns}$ \\
$\mathrm{DM}$ & 11,98 & $2,046 \mathrm{~ns}$ & $11,405^{* *}$ & $0,005 \mathrm{~ns}$ \\
$\mathrm{CE}$ & 7,84 & $0,295 \mathrm{~ns}$ & $33,257^{* *}$ & $0,591 \mathrm{~ns}$ \\
$\mathrm{TP}$ & 4,31 & $1,827^{*}$ & $8,799^{* *}$ & $1,745 \mathrm{~ns}$ \\
$\mathrm{M} 100$ & 3,18 & $4,145 \mathrm{~ns}$ & $0,338 \mathrm{~ns}$ & $6,851^{* *}$ \\
$\mathrm{G}$ & 13,90 & $459,493^{* *}$ & $1,328 \mathrm{~ns}$ & $9,327^{* *}$ \\
$\mathrm{AN}$ & 19,89 & $736,763 \mathrm{~ns}$ & $3,428 \mathrm{~ns}$ & $7,824^{* *}$ \\
$\mathrm{EA}$ & 22,22 & $134,564^{* *}$ & $10,685^{* *}$ & $0,006 \mathrm{~ns}$ \\
$\mathrm{CR}$ & 26,47 & $239,415^{* *}$ & $0,015 \mathrm{~ns}$ & $7,730^{* *}$ \\
$\mathrm{CH}$ & 25,43 & $41,639^{* *}$ & $12,217^{* *}$ & $18,506^{* *}$ \\
$\mathrm{CT}$ & 22,67 & $222,825^{* *}$ & $1,588 \mathrm{~ns}$ & $15,794^{* *}$ \\
$\mathrm{MS}$ & 18,83 & $2,647 \mathrm{~ns}$ & $12,830^{* *}$ & $0,333 \mathrm{~ns}$ \\
\hline
\end{tabular}

** e $\mathrm{e}^{*}$ significativo a 1 e $5 \%$ de probabilidade, respectivamente; ns: não significativo.

TZ1-5: sementes viáveis; DM: dano mecânico; CE: condutividade elétrica; TP: teor de proteína; M100: massa de 100 sementes; G: germinação; AN: plântulas anormais do teste de germinação; EA: envelhecimento acelerado; CR: comprimento da raiz primária; CH: comprimento do hipocótilo; CT: comprimento total da plântula; MS: massa da matéria seca das plântulas.

Tabela 3. Viabilidade $\left(\mathrm{TZ}_{1-5}, \%\right)$, dano mecânico (DM, \%), condutividade elétrica $\left(\mu \mathrm{S} \mathrm{cm}^{-1} \mathrm{~g}^{-1}\right)$ e teor de proteína (TP, \%) de sementes de soja colhidas em diferentes épocas após a dessecação das plantas com glyphosate.

\begin{tabular}{ccccc}
\hline \multirow{2}{*}{ Avaliação } & Dessecação & \multicolumn{2}{c}{ Dias após dessecação } & \multirow{2}{*}{ Média } \\
\cline { 3 - 4 } & & 7 & 14 & 93 \\
\multirow{2}{*}{$\mathrm{TZ}_{1-5}$} & Com & $92^{(1)}$ & 94 & 93 \\
& Sem & 93 & 92 & - \\
\hline \multirow{2}{*}{$\mathrm{DM}^{(2)}$} & Média & 93 & 93 & 5 \\
& Com & 4 & 6 & 6 \\
& Sem & 4 & 7 & - \\
\hline \multirow{2}{*}{$\mathrm{CE}$} & Média & $4 \mathrm{~A}$ & $6 \mathrm{~B}$ & 75,85 \\
& Com & 70,96 & 80,73 & 76,66 \\
& Sem & 72,92 & 80,39 & - \\
\hline & Média & $71,94 \mathrm{~A}$ & $80,56 \mathrm{~B}$ & 26,35 \\
& Com & 26,11 & 26,58 & 26,74 \\
& Sem & 26,12 & 27,35 & - \\
\hline
\end{tabular}

(1) Médias seguidas pela mesma letra minúscula na coluna e maiúscula na linha não diferem entre si pelo teste de Tukey $(p \leq 0,05)$.

${ }^{(2)}$ Dados transformados em arc sen $\sqrt{ }(\mathrm{x} / 100)+0,5$.

A ocorrência de danificações mecânicas às sementes de soja variou com a época de colheita das mesmas após a dessecação, devido, possivelmente, ao método de colheita empregado em função de variações no teor de água (Tabela 3). A colheita mais tardia, realizada mecanicamente com colhedora automotriz, proporcionou maiores danos às 
sementes do que a colheita manual das plantas prosseguida de debulha mecânica das plantas inteiras e secas, empregada na primeira época. Os valores observados não ultrapassaram $10 \%$, limite percentual máximo referido por Krzyzanowski et al. (2004) em lotes de sementes de soja, entretanto, as danificações mecânicas, possivelmente, influenciaram negativamente os valores de condutividade elétrica, ligeiramente superior em sementes colhidas 14 dias após a dessecação. Contrariamente, a época de colheita mais tardia, após a aplicação do glyphosate, proporcionou aumento do teor de proteína das sementes.
A massa de sementes de soja foi reduzida em função da dessecação em pré-colheita com glyphosate, mas somente em avaliação realizada 7 dias após a aplicação (Tabela 4); sementes produzidas por plantas não dessecadas apresentaram menor massa quando da colheita mais tardia, já que à medida que as sementes permanecem no campo, iniciam-se os processos de deterioração (Carvalho e Nakagawa, 2000). A massa de sementes não foi influenciada pelas épocas após a dessecação das plantas possivelmente devido à redução mais gradual do teor de água no intervalo entre as colheitas, fato não verificado na ausência de aplicação do glyphosate.

Tabela 4. Massa de 100 semenetes (M100, g), germinação (G, \%), plântulas anormais do teste de germinação (AN, \%) e envelhecimento acelerado (EA, \%) de sementes de soja colhidas em diferentes épocas após a dessecação das plantas com glyphosate.

\begin{tabular}{ccccc}
\hline \multirow{2}{*}{ Avaliação } & \multirow{2}{*}{ Dessecação } & \multicolumn{2}{c}{ Dias após dessecação } & \multirow{2}{*}{ Média } \\
\cline { 3 - 4 } & & 7 & 14 & $19,02 \mathrm{~b}$ \\
\multirow{3}{*}{ M100 } & Com & $18,91 \mathrm{bA}^{(1)}$ & $19,13 \mathrm{aA}$ & $19,23 \mathrm{a}$ \\
& Sem & $19,41 \mathrm{aA}$ & $19,06 \mathrm{aB}$ & - \\
\hline \multirow{3}{*}{$\mathrm{G}$} & Média & 19,16 & 19,09 & $39 \mathrm{~b}$ \\
& Com & $44 \mathrm{bA}$ & $35 \mathrm{bB}$ & $86 \mathrm{a}$ \\
& Sem & $84 \mathrm{aA}$ & $88 \mathrm{aA}$ & - \\
\hline \multirow{2}{*}{ AN } & Média & 64 & 61 & $53 \mathrm{~b}$ \\
& Com & $50 \mathrm{bA}$ & $57 \mathrm{bB}$ & - \\
\hline \multirow{2}{*}{ EA } & Sem & $11 \mathrm{aA}$ & $10 \mathrm{aA}$ & $38 \mathrm{~b}$ \\
& Média & 30 & 33 & $75 \mathrm{a}$ \\
\hline
\end{tabular}

(1) Médias seguidas pela mesma letra minúscula na coluna e maiúscula na linha não diferem entre si pelo teste de Tukey ( $p \leq 0,05)$.

De acordo com a Tabela 4, a germinação das sementes de soja, antes e após o envelhecimento acelerado, foi reduzida significativamente com a dessecação das plantas de soja em pré-colheita, devido ao aumento da porcentagem de plântulas anormais. A germinação após o envelhecimento acelerado também foi reduzida em função do atraso da colheita após a aplicação, assim como o número de plântulas anormais do teste de germinação, sendo que este foi elevado em interação com o emprego da dessecação. Gazziero e França-Neto (2008) e Daltro et al. (2010), em cultivares convencionais de soja, também observaram que o glyphosate interfere negativamente na germinação e desenvolvimento inicial das plântulas.

O glyphosate possui ação sistêmica dentro da planta e é rapidamente translocado quando aspergido sobre folhas e vagens (Duke, 1988). No entanto, devido à aplicação do produto no estádio de maturidade fisiológica, ocasião em que a translocação de fotoassimilados da planta para a semente é praticamente cessada (Carvalho e Nakagawa, 2000). Assim, não é esperado constatar efeitos negativos da dessecação na qualidade das sementes devido ao acúmulo de resíduos tóxicos. Apesar disso, pode ter havido absorção local do glyphosate, aspergido diretamente sobre as vagens, além de posterior degradação das moléculas e formação de metabólitos secundários. Dentre tais metabólitos, pode haver formação de AMPA (ácido aminometilfosfônico), que é o principal metabólito secundário (Mattos et al., 2002) 
e pode ser acumulado nas sementes (Duke et al., 2003). Portanto, a presença de AMPA em sementes de soja pode ser um agente nocivo na fisiologia destas e desencadeador de distúrbios que levam à geração de plântulas anormais.

O comprimento da raiz primária, do hipocótilo e total das plântulas de soja foi reduzido pela aplicação de glyphosate como dessecante em pré-colheita e pela colheita na primeira semana após a aplicação do herbicida (Tabela 5). Funguetto et al. (2004) esclareceram que, na presença do glyphosate, os processos fisiológicos capazes de garantir o desenvolvimento das plântulas de cultivares não modificados geneticamente são drasticamente afetados. Efeitos fitotóxicos causados pela aplicação de glyphosate, traduzidos por menor desenvolvimento das raízes de plântulas, também foram constatados em cultivares convencionais de soja por Gazziero e FrançaNeto (2008) e Daltro et al. (2010), após aplicações do herbicida em pré-colheita.

Contrariamente ao constatado na germinação (Tabela 4), a colheita mais tardia das sementes após a aplicação do glyphosate proporcionou produção de plântulas de soja, e de suas partes constituintes, com maior comprimento, comparativamente à $1^{\text {a }}$ época (Tabela 5). O atraso na colheita e consequente exposição prolongada das sementes às condições do ambiente no campo minimizaram a ocorrência dos sintomas fitotóxicos no crescimento das plântulas. É importante destacar, porém, que a aplicação do herbicida ocasionou redução do desenvolvimento das plântulas em quaisquer épocas de colheita, comparativamente à ausência de dessecação.

Tabela 5. Comprimento da raiz primária $(\mathrm{CR}, \mathrm{cm})$, do hipocótilo $(\mathrm{CH}, \mathrm{cm})$ e total $(\mathrm{CT}, \mathrm{cm})$ de plântulas e massa da matéria seca (MS, mg) de plântulas de soja oriundas de sementes colhidas em diferentes épocas após a dessecação das plantas com glyphosate.

\begin{tabular}{ccccc}
\hline \multirow{2}{*}{ Avaliação } & Dessecação & \multicolumn{2}{c}{ Dias após dessecação } & \multirow{2}{*}{ Média } \\
\cline { 3 - 4 } & & 7 & 14 & $3,81 \mathrm{~b}$ \\
$\mathrm{n}$ & Com & $3,06 \mathrm{bB}$ & $4,56 \mathrm{bA}$ & $11,81 \mathrm{a}$ \\
& Sem & $12,50 \mathrm{aA}$ & $11,13 \mathrm{aA}$ & - \\
\hline \multirow{2}{*}{$\mathrm{CH}$} & Média & 7,78 & 7,84 & $2,91 \mathrm{~b}$ \\
& Com & $2,00 \mathrm{bB}$ & $3,81 \mathrm{aA}$ & $4,41 \mathrm{a}$ \\
& Sem & $4,50 \mathrm{aA}$ & $4,31 \mathrm{aA}$ & - \\
\hline \multirow{2}{*}{$\mathrm{CT}$} & Média & $3,25 \mathrm{~B}$ & $4,06 \mathrm{~A}$ & $6,56 \mathrm{~b}$ \\
& Com & $4,88 \mathrm{bB}$ & $8,25 \mathrm{bA}$ & - \\
\hline \multirow{2}{*}{$\mathrm{MS}$} & Sem & $17,06 \mathrm{aA}$ & $15,31 \mathrm{aA}$ & 30,66 \\
& Média & 10,97 & 11,78 & 33,11 \\
& Com & 33,78 & 27,54 & - \\
\hline
\end{tabular}

${ }^{(1)}$ Médias seguidas pela mesma letra minúscula na coluna e maiúscula na linha não diferem entre si pelo teste de Tukey ( $\left.p \leq 0,05\right)$.

\section{Conclusões}

A dessecação das plantas de soja em pré-colheita com glyphosate causa redução da germinação das sementes e do desenvolvimento inicial das plântulas.

$\mathrm{O}$ atraso na colheita reduz a germinação das sementes oriundas de plantas de soja dessecadas com glyphosate em pré-colheita, mas minimiza os efeitos fitotóxicos no desenvolvimento das plântulas.

\section{Agradecimentos}

À Fundação de Amparo à Pesquisa do Estado de São Paulo (FAPESP), pela concessão da bolsa de estudos ao primeiro autor durante o curso de Doutorado.

\section{Referências}

AOAC. Association of Official Analytical Chemists. Official methods of analysis. 15.ed. Arlington: AOAC, 1990. 684p. 
BRASIL. Ministério da Agricultura, Pecuária e Abastecimento. Regras para análise de sementes. Ministério da Agricultura, Pecuária e Abastecimento. Secretaria de Defesa Agropecuária. Brasília, DF: MAPA/ ACS, 2009. 395p. http://www.agricultura.gov.br/arq_editor/file/2946_ regras_analise_sementes.pdf

CARVALHO, N.M.; NAKAGAWA, J. Sementes: ciência, tecnologia e produção. 4.ed. Jaboticabal: FUNEP, 2000. 588p.

DALTRO, E.M.F.; ALBUQUERQUE, M.C.F.; FRANÇA-NETO, J.B.; GUIMARÃES, S.C.; GAZZIERO, D.L.P.; HENNING, A.A. Aplicação de dessecantes em pré-colheita: efeito na qualidade fisiológica de sementes de soja. Revista Brasileira de Sementes, v.32, n.1, p.111-122, 2010. http: www.scielo.br/pdf/rbs/v32n1/v32n1a13.pdf

DUKE, S.O. Glyphosate. In: KEARNEY, P.C.; KAUFMAN, D.D. (Eds.). Herbicides: chemistry, degradation, and mode of action. New York: Dekker, 1988. v.3, p.1-70.

DUKE, S.O.; RIMANDO, A.M.; PACE, P.F.; REDDY, N.K.; SMEDA, R.J. Isoflavone, glyphosate and aminomethylphosphonic acid levels in seeds of glyphosate-treated, glyphosate-resistant soybean. Journal of Agriculture and Food Chemistry, v.51, n.1, p.340-344, 2003.

EMBRAPA. Centro Nacional e Pesquisa em Solos. Sistema Brasileiro de Classificação de Solos. Brasília: Embrapa SPI; Rio de Janeiro: Embrapa Solos, 2006. 306p.

FEHR, W.R.; CAVINESS, C.E. Stages of soybean development. Ames: Iowa Agricultural Experimental Station, 1977. 11p. (Special Report, 80).

FRANÇA-NETO, J.B.; KRZYZANOWSKI, F.C.; PÁDUA, G.P.; COSTA, N.P.; HENNING, A.A. Tecnologia da produção de semente de soja de alta qualidade - Série Sementes. Londrina: Embrapa Soja, 2007. 12p. (Circular Técnica, 40). http: www.infoteca.cnptia.embrapa.br/ bitstream/doc/467586/1/circtec40.pdf

FRANÇA-NETO, J.B.; KRYZANOWSKI, F.C.; SILVA, W.R. O teste de tetrazólio em sementes de soja. Londrina: Embrapa Soja, 1998. 72p. (Documentos, 116). http://www.infoteca.cnptia.embrapa.br/bitstream/ doc/461306/1/doc116.pdf

FUnGUeTto, C.I.; TILLMANN, M.A.A.; VILLELA, F.A.; DODE, L.B. Detecção de sementes de soja geneticamente modificada tolerante ao herbicida glifosato. Revista Brasileira de Sementes, v.26, n.1, p.130-138, 2004. http://www.scielo.br/pdf/rbs/v26n1/a20v26n1.pdf

GAZZIERO, D.L.P.; FRANÇA-NETO, J.B. Dessecação em pré-colheita e seus efeitos sobre a qualidade da semente de soja. http://www.cnpso. embrapa.br/ download/palestras/glyphosate-dionisio-franca.pdf. Acesso em 21 jul. 2008.

HAMER, E.; HAMER, E. Produção de sementes requer planejamento. Seed News, ano VII, n.4, p.23-27, 2003. http://www.seednews.inf.br/ portugues/seed74/especial74.shtml

INOUE, M.H.; MARCHIORI JR., O.; BRACCINI, A.L.; OLIVEIRA
JR., R.S.; ÁVILA, M.R.; CONSTANTIN, J. Rendimento de grãos e qualidade de sementes de soja após a aplicação de herbicidas dessecantes. Ciência Rural, v.33, n.4, p.769-770, 2003. http://www.scielo.br/pdf/cr/ v33n4/16704.pdf

KAPPES, C.; CARVALHO, M.A.C.; YAMASHITA, O.M. Potencial fisiológico de sementes de soja dessecadas com diquat e paraquat. Scientia Agraria, v.10, n.1, p.1-6, 2009. http://dialnet.unirioja.es/servlet/ fichero_articulo?codigo $=2900637 \&$ orden $=0$

KRZYZANOWSKI, F.C.; FRANÇA-NETO, J.B.; COSTA, N.P. Teste do hipoclorito de sódio para semente de soja. Londrina: Embrapa Soja, 2004. 4p. (Circular técnica, 37). http://www.fag.edu.br/professores/ elsantos/Tecnologia\%20e\%20Produ\%E7\%E3o\%20de\%20Sementes/ Teste\%20de\%20Hipoclorito.pdf

LACERDA, A.L.S.; LAZARINI, E.; SÁ, M.E.; VALÉRIO FILHO, W.V. Aplicação de dessecantes na cultura da soja: teor de umidade nas sementes e biomassa nas plantas. Planta Daninha, v.21, n.3, p.427434, 2003. http://www.scielo.br/scielo.php?script=sci_arttext\&pid $=\mathrm{S} 0100-83582003000300011$

MARCOS-FILHO, J. Teste de envelhecimento acelerado. In: KRZYZANOWSKI, F.C.; VIEIRA, R.D.; FRANÇA-NETO, J.B. (Ed.). Vigor de sementes: conceitos e testes. Londrina: ABRATES, 1999. 218p.

MARCOS-FILHO, J. Fisiologia de sementes de plantas cultivadas. Piracicaba: FEALQ, 2005. 495p.

MATTOS, M.L.T.; PERALBA, M.C.R.; DIAS, S.L.P.; PRATA, F.; CAMARGO, L. Monitoramento ambiental do glifosato e do seu metabólito (ácido aminometilfosfônico) na água de lavoura de arroz irrigado. Revista Ecotoxicologia e Meio Ambiente, v.12, p.143-154, 2002. http://ojs.c3sl.ufpr.br/ojs2/index.php/pesticidas/article/view/3156/2529

NAKAGAWA, J. Testes de vigor baseados no desempenho das plântulas. In: KRZYZANOWSKI, F.C.; VIEIRA, R.D.; FRANÇA-NETO, J.B. (Ed.). Vigor de sementes: conceitos e testes. Londrina: ABRATES, 1999. cap.2, p.2-24.

RAIJ, B. VAN; CANTARELLA, H.; QUAGGIO, J.A.; FURLANI, A.M.C. Recomendações de adubação e calagem para o Estado de São Paulo. 2.ed. Campinas: IAC, 1996. 285p. (Boletim Técnico, 100).

VANZOLINI, S.; ARAKI, C.A.S.; SILVA, A.C.T.M.; NAKAGAWA, J. Teste de comprimento de plântula na avaliação da qualidade fisiológica de sementes de soja. Revista Brasileira de Sementes, v.29, n.2, p.90-96, 2007. http://www.scielo.br/pdf/rbs/v29n2/v29n2a12.pdf

VARGAS, L.; MORAES, R.M.A.; BERTO, C.M. Herança da resistência de azevém (Lolium multiflorum) ao glyphosate. Planta Daninha, v.25, n.3, p.567571, 2007. http://www.scielo.br/pdf/pd/v25n3/16.pdf

VIEIRA, R.D.; KRZYZANOWSKI, F.C. Teste de condutividade elétrica. In: KRZYZANOWSKI, F.C.; VIEIRA, R.D.; FRANÇA-NETO, J.B. (Ed.). Vigor de sementes: conceitos e testes. Londrina: ABRATES, 1999. p.1-26. 